\title{
Article \\ Effects of Deficit Irrigation Scheduling on Water Use, Gas Exchange, Yield, and Fruit Quality of Date Palm
}

\author{
Maged Mohammed ${ }^{1,2, *} \mathbb{C}$, Abdelkader Sallam ${ }^{3}$, Muhammad Munir ${ }^{1} \mathbb{D}$ and Hassan Ali-Dinar ${ }^{1}$ \\ 1 Date Palm Research Center of Excellence, King Faisal University, Hofuf 31982, Saudi Arabia; \\ mmunir@kfu.edu.sa (M.M.); hdinar@kfu.edu.sa (H.A.-D.) \\ 2 Department of Agricultural and Biosystems Engineering, Faculty of Agriculture, Menoufia University, \\ Shebin El-Koum 32514, Egypt \\ 3 Plant Production Department, College of Technology and Development, Zagazig University, \\ Zagazig 44519, Egypt; aasallam@yahoo.com \\ * Correspondence: memohammed@kfu.edu.sa
}

Citation: Mohammed, M.; Sallam, A.; Munir, M.; Ali-Dinar, H. Effects of Deficit Irrigation Scheduling on Water Use, Gas Exchange, Yield, and Fruit Quality of Date Palm. Agronomy 2021 11, 2256. https://doi.org/10.3390/ agronomy11112256

Academic Editors: Ignacio Buesa and Carlos Ballester Lurbe

Received: 29 September 2021

Accepted: 4 November 2021

Published: 8 November 2021

Publisher's Note: MDPI stays neutral with regard to jurisdictional claims in published maps and institutional affiliations.

Copyright: (c) 2021 by the authors. Licensee MDPI, Basel, Switzerland. This article is an open access article distributed under the terms and conditions of the Creative Commons Attribution (CC BY) license (https:// creativecommons.org/licenses/by/ $4.0 /)$.

\begin{abstract}
Water scarcity is very common in the arid region due to the low yearly rainfall. The cost of water for agricultural usage is extremely high in dry locations. Date palm is a high water-demanding tree throughout the year in arid regions. Therefore, the application of deficit irrigation strategies for date palm cultivation may significantly contribute to conserving irrigation water. The present study aimed to assess the effects of controlled deficit irrigation using two modern micro-irrigation systems on water use efficiency (WUE), gas exchange, fruit yield, and quality of date palm (Khalas cv.). The irrigation systems included drip irrigation (DI) and subsurface irrigation (SI) systems. The study was conducted during the 2020 and 2021 seasons at the Date Palm Research Center of Excellence, King Faisal University, Saudi Arabia. The meteorological variables of the study area were real-time monitored using cloud-based IoT (Internet of Things) to calculate the evapotranspiration reference (ETo) and control the irrigation scheduling. Three irrigation treatments $(50,75$, and $100 \% \mathrm{ETc})$ were applied using DI and SI systems compared with the traditional surface bubbler irrigation (Control). The actual applied water at the deficit irrigation treatments of 50, 75, and $100 \%$ ETc were $27.28 \pm 0.06$, $44.14 \pm 1.07$, and $55.55 \pm 0.37 \mathrm{~m}^{3}$ palm ${ }^{-1}$, respectively. At all deficit irrigation treatments, the leaf chlorophyll and gas exchange were significantly higher in the SI compared to the DI system. The yield of date palms did not differ significantly between the control and SI systems at both the level of 100 and $75 \%$ ETc. The WUE under the SI $\left(1.09 \mathrm{~kg} \mathrm{~m}^{-3}\right)$ was significantly higher than the DI system $\left(0.52 \mathrm{~kg} \mathrm{~m}^{-3}\right)$ at the $50 \%$ level. There was no significant difference regarding the fruit quality parameters between SI at 50\% ETc and control at 100\% ETc. Therefore, adopting deficit irrigation strategies using the SI system at 50\% ETc level throughout the year could be suggested for date palm irrigation to save water, improve WUE, and maintain fruit quality.
\end{abstract}

Keywords: micro-irrigation systems; irrigation management; arid region; water scarcity; water use efficiency; cloud-based IoT; Ubidots; IFTTT

\section{Introduction}

Crops in arid regions mainly rely on irrigation. These regions are mostly deserts characterized by irrigation water scarcity, which is a major constraint for sustainable agriculture and economic development [1-3]. In addition, the population growth needs sustained growth of food production in the future, which requires irrigation water inputs that can support irrigated cultivation [4,5]. Irrigation for food production is the largest consumer of freshwater resources globally, accounting for approximately $70 \%$ of total withdrawals [6]. However, less than $60 \%$ of the irrigation water applied is efficiently utilized by the crops [7]. Despite water scarcity, flood irrigation is still practiced in many areas around the world. Therefore, researchers are focusing more on plant water requirements and supply alternatives for water management as a critical component of assuring the efficacy of water-saving 
irrigation systems that rely on irrigating plants with less water [8]. Even though using desalinated seawater and reclaimed water to irrigate crops can benefit, the high energy demand, reclaimed water's risk, and the costs of desalination water impede its economical use $[5,9,10]$.

Date palm (Phoenix dactylifera L.) is an essential crop in the arid region including Saudi Arabia. It is cultivated on 1,396,727 hectares with a global annual production of $9,248,033$ tonnes. In Saudi Arabia, it is grown on 117,881 hectares with a yearly production of $1,539,756$ tonnes [11]. It is a valuable resource for desert dwellers, since it supplies the best food as well as building materials. The date fruit is used in a range of confectionaries and sweet dishes in addition to its ornamental value. This plant's parts have been used in medicine in a variety of ways [12,13]. Surface irrigation systems used in date palm orchards include the flood irrigation system, furrow / basin irrigation system, drip irrigation system, bubbler irrigation system, sprinkler irrigation system, etc. [13]. Although date palm is considered a drought-tolerant crop, its growth, yield, and fruit quality are severely affected by lack of water supply [3,14]. Proper water management for sustainable date palm cultivation in arid environments is key for scientists and related stakeholders. Furthermore, while conventional surface irrigation methods produce the maximum date palm yield, modern micro-irrigation systems with reduced irrigation water application can also produce similar yield [15-17]. Globally, there are several ongoing efforts to design modern irrigation systems to improve irrigation water management and reduce irrigation water inputs without significant impact on crop yield and fruit quality [3,18-20].

The traditional irrigation systems are based on the meteorological conditions and each plant's need, which is the main challenge [21]. Appropriate irrigation water scheduling contributes to higher crop yield and WUE [22]. When there is limited water supply available throughout the cropping period, the irrigation schedule is adjusted to protect plants from excessive water stress during the most sensitive crop growth periods. Growers who adopt irrigation scheduling procedures use modern equipment to determine the amount of water needed by the crop. Deficit irrigation, soil moisture sensors, and subsurface drip irrigation are all options for sustainable water management irrigation scheduling [23]. However, it is difficult to change the irrigation water amount or frequency when conventional irrigation systems are used $[5,14,24,25]$.

The annual water requirement for date palm (Sukariah cv.) in a DI system was varied using two methods: a water-balance technique $(1640 \mathrm{~mm})$ and a Bowen ratio energy balance method $(1780 \mathrm{~mm})$ [26]. According to another study, the SI system increased the WUE and yield of date palms while reducing the amount of applied water [27]. It was also claimed that increasing WUE with the SI technique increased date palm yields by 25-60\% [27-29]. Similarly, by reducing the amount of applied water from 100\% ETc to $70 \%$ ETc, a $6 \%$ increase in date palm yield was achieved [30]. Moreover, the crop water potential of the SI system was much higher than the bubbler irrigation system in date palm farming [31]. In addition, the low water-dispensing driplines decreased the irrigation water amount by $49-53 \%$ while increasing the yield of date palm by $45-49 \%$ when compared to medium and high-frequency water dispensing driplines used in SI systems [28]. In the region of the Baluchestan province of Iran, the deficit irrigation of $70 \%$ ETc at intervals of $100 \mathrm{~mm}$ evaporation gave the highest WUE and yield without any loss of fruit quality of date palm [30].

In perennial plants, a small amount of the water absorbed by the roots is used in photosynthesis and biomass formation, while the most are returned to the environment through transpiration. Stomatal closure is one of the most important mechanisms used by plants to limit the amount of water that evaporates into the atmosphere [32]. When there is a water shortage, the relative water content of the leaves decreases, which causes stomatal conductance, photosynthetic rate, and transpiration to decrease [33]. The water stress lowered the photosynthetic rate and stomatal conductance in citrus, and it significantly increased WUE at the moderate water deficit level [34]. In an in vitro study, water stress negatively affected gas exchange in date palm cultivars, whereas intrinsic WUE was 
increased [35]. In another study, chlorophyll $a$ and $b$ in sweet basil were observed to be in high levels at moderate and severe water stress [36].

Mohammed et al. [14] developed an automated SI system controlled by a cloud-based IoT platform to improve irrigation management of date palms. They reported that the SI system with time-based irrigation scheduling positively influenced the yield of date palm and WUE. Furthermore, due to the enormous IoT revolution and the development of sensors for intelligent agriculture, its use has a substantial impact on crop production and irrigation water conservation [37]. Cloud computing and IoT technologies have also improved connectivity and remote control between the user and the farm. As a result, multi-tier cloud IoT and computing platforms are used to control, monitor, and manage crop farming in a fully automated system. This will address the issues of water scarcity and labor shortages [5,38-40]. Therefore, the current study was conducted with the main goal of determining the effects of controlled deficit irrigation on water use, gas exchange, fruit yield, and quality of date palm in an arid environment through the following means:

1- Real-time monitoring and recording of the climatic conditions of the study area using cloud-based IoT to calculate the evapotranspiration reference (ETo) and control the irrigation scheduling.

2- Assessing two modern micro-irrigation systems (DI and SI) under three deficit irrigation treatments $(50,75$, and 100\% ETc) compared with the traditional surface bubbler irrigation system (Control).

\section{Materials and Methods}

\subsection{Site Description}

This study was conducted during the years 2020-2021 at the Date Palm Research Center of Excellence (DPRC), King Faisal University (KFU), Saudi Arabia (Latitude 25 $16^{\prime} 24.452^{\prime \prime}$ N, Longitude $49^{\circ} 42^{\prime} 28.595^{\prime \prime} \mathrm{E}$ ). The experimental field included 13-year-old full-grown date palm trees (Khalas cv.) with a density of $200 \mathrm{palm} \mathrm{ha}^{-1}$. The in-row and between rows palm distances were $7 \mathrm{~m}$. The average physicochemical and hydraulic characteristics of the experimental soil at $100 \mathrm{~cm}$ depth are indicated in Table 1 . The water source used in this study was supplied from groundwater wells. The electrical conductivity, $\mathrm{pH}$, and total dissolved solids of the irrigation water were $0.98 \pm 0.61 \mathrm{dS} \mathrm{m}^{-1}, 9.3 \pm 1.01$, and $786 \pm 48.32 \mathrm{mg} \mathrm{L}^{-1}$, respectively.

Table 1. Average \pm standard deviation of some physicochemical and hydraulic characteristics of the experimental soil.

\begin{tabular}{|c|c|c|c|c|c|c|c|c|}
\hline & \multicolumn{3}{|c|}{ Particle Size } & \multirow{2}{*}{$\begin{array}{l}\text { FC } \\
(\%)\end{array}$} & \multirow{2}{*}{$\begin{array}{c}\text { PWP } \\
(\%)\end{array}$} & \multirow{2}{*}{$\underset{(1: 2.5)}{\mathrm{pH}}$} & \multirow{2}{*}{$\begin{array}{c}\mathrm{EC} \\
\left(\mathrm{dS} \mathrm{m}^{-1}\right)\end{array}$} & \multirow{2}{*}{$\begin{array}{c}\mathrm{HC} \\
\left(\mathrm{cm} \mathrm{h}^{-1}\right)\end{array}$} \\
\hline & Sand $(\%)$ & Silt (\%) & Clay (\%) & & & & & \\
\hline Mean & 74.77 & 11.22 & 14.01 & 14.34 & 5.323 & 8.345 & 3.814 & 5.213 \\
\hline St. Dev. & 3.592 & 1.553 & 5.012 & 0.751 & 0.282 & 0.181 & 0.132 & 0.162 \\
\hline
\end{tabular}

FC is field capacity of the soil, $\mathrm{PWP}$ is permanent wilting point, $\mathrm{pH}$ is hydrogen ions concentration, EC is electrical conductivity, and HC is hydraulic conductivity.

\subsection{Irrigation Systems}

The irrigation systems consisted of a water source, water pump $(1.5 \mathrm{~kW})$, irrigation network with manifolds to connect the tubes of the irrigation network, manual valves, solenoid valves, pressure regulator (Model: DN20, OEM, Zhejiang, China), pressure gauge, digital flow meter (Model: K24-S, SUNNY, Shandong, China), and control system (Figure 1). The irrigation network included the irrigation mainline, sub mains, and feeder ring pipe made of HDPE (high-density polyethylene) with $5,2.5$, and $1.25 \mathrm{~cm}$ diameters. The disc filters with 120 mesh (120 microns) were used for water filtration. The control system included the electronic devices and power source of sensors. The power source of the con-trol system was taken from a photovoltaic system, including a battery $(12 \mathrm{~V}, 35 \mathrm{Ah})$, $20 \mathrm{~W}$ solar panel, and charging regulator. The solenoid valves were used to control water flow shut on/off based on the irrigation water scheduling applied to each palm tree. 


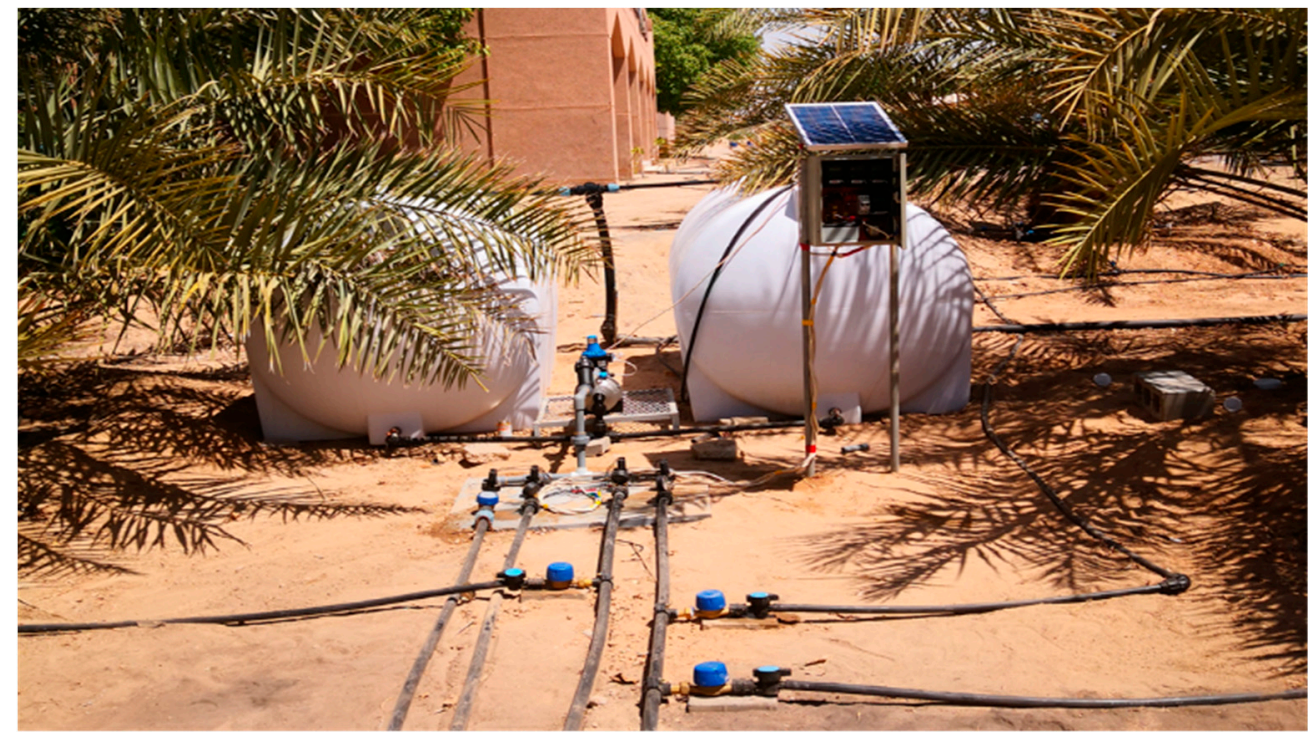

Figure 1. Experimental setup of the irrigation systems.

Therefore, six subsurface irrigation (SI) units were used per date palm tree in the SI system (Figure 2A). The SI unit consisted of two perforated pipes with gravel between them and a water flow adjuster. The inner diameter of the SI unit was 12 and $35 \mathrm{~cm}$ in length (Figure 2B). Light volcanic gravel $(0.04-0.08 \mathrm{~cm})$ was placed between the two pipes to reduce the water amount inside the SI unit. The flow rate of the SI unit was at $0.030 \mathrm{~m}^{3} \mathrm{~h}^{-1}$ using an adjustable dripper (Model: AY 2001- Red/black, Baoding Anyou Industry Co., Ltd. Baoding, Hebei province, China) at the pressure of $300 \mathrm{kPa}$. The six SI units were buried around the date palm in a circle with a diameter of $120 \mathrm{~cm}$. The laterals transferred irrigation water to these units, as shown in Figure 3.
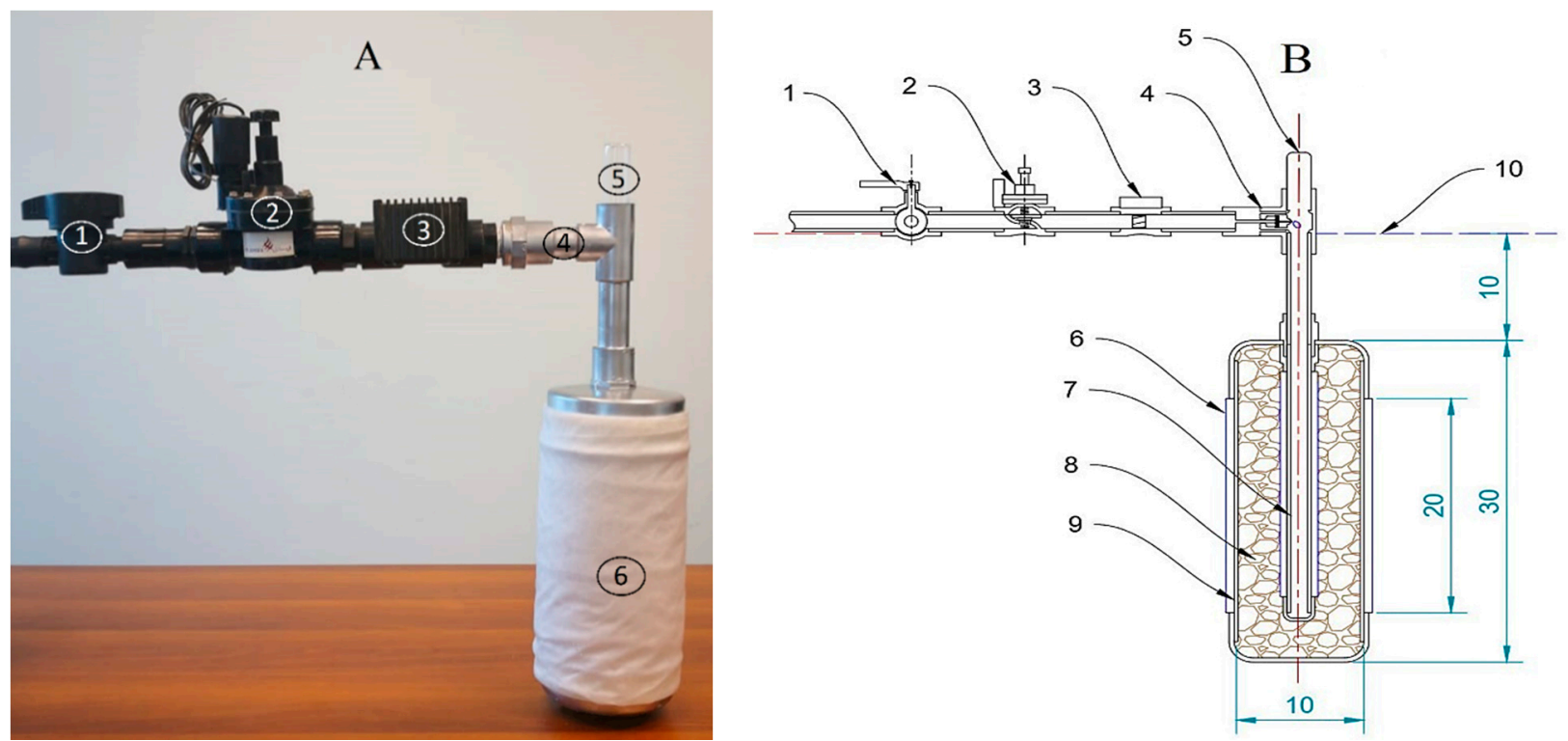

Figure 2. Image (A) and schematic diagram (B) of the subsurface irrigation unit. (1) Manual valve, (2) Electronic valve, (3) Digital flowmeter, (4) Twistable dripper head, (5) Glass cover, (6) Filtering cloth of the outer pipe, (7) The inner pipe, (8) Light volcanic gravel, (9) Slotted outer pipe, (10) Soil level. All dimensions are in centimeters. 


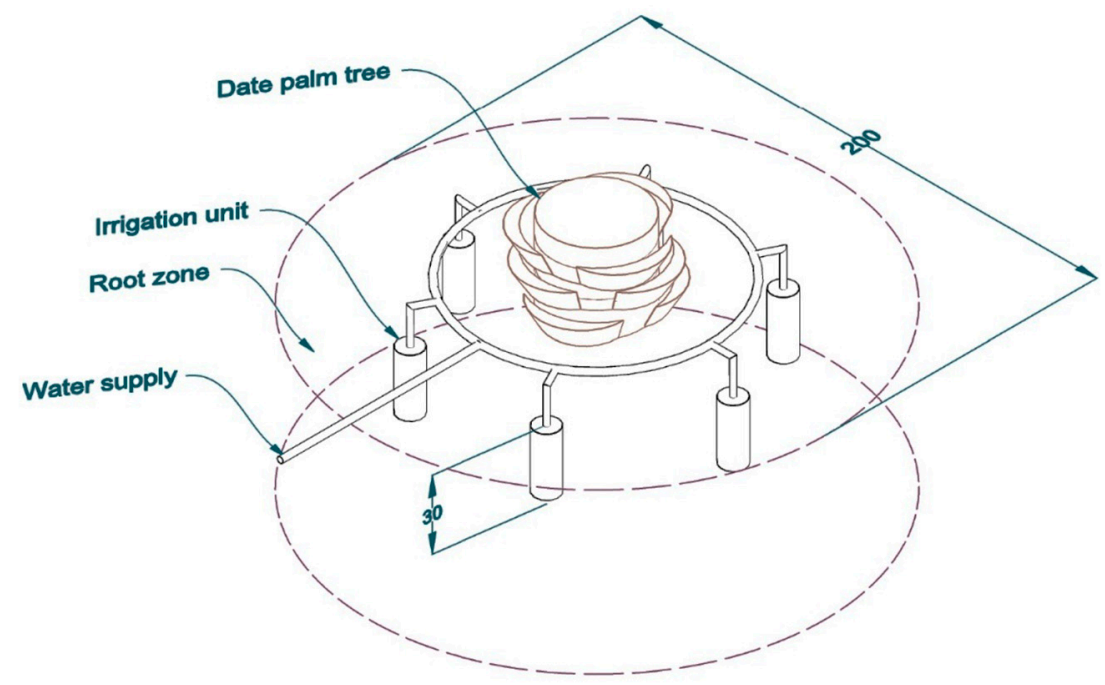

Figure 3. The six subsurface irrigation units distributed equally around the date palm tree in the target irrigation area with a diameter of $200 \mathrm{~cm}$.

Figure 4 shows a comparison between the distribution of the six irrigation units in the surface irrigation system (Figure 4A) and the distribution of the six drippers around the palm trees (Figure 4B). In the drip irrigation system (DI), six pressure compensating drippers (Model: Anyou 30L/H-green/black, Baoding Anyou Industry Co., Ltd. Baoding, Hebei province, China) per date palm tree were used to maintain constant irrigation water flow for the irrigation line. Figure $4 \mathrm{~B}$ shows the distribution of the six drippers around the date palm tree. When irrigation water was applied for $60 \mathrm{~min}$ to the soil with a flow rate of $0.030 \mathrm{~m}^{3} \mathrm{~h}^{-1}$, a wetted circle with a diameter of $65 \pm 4.9 \mathrm{~cm}$ was formed on the soil surface. Therefore, the irrigation network pressure was adjusted at $300 \mathrm{kPa}$ to allow a flow rate of the dripper within $0.030 \mathrm{~m}^{3} \mathrm{~h}^{-1}$.

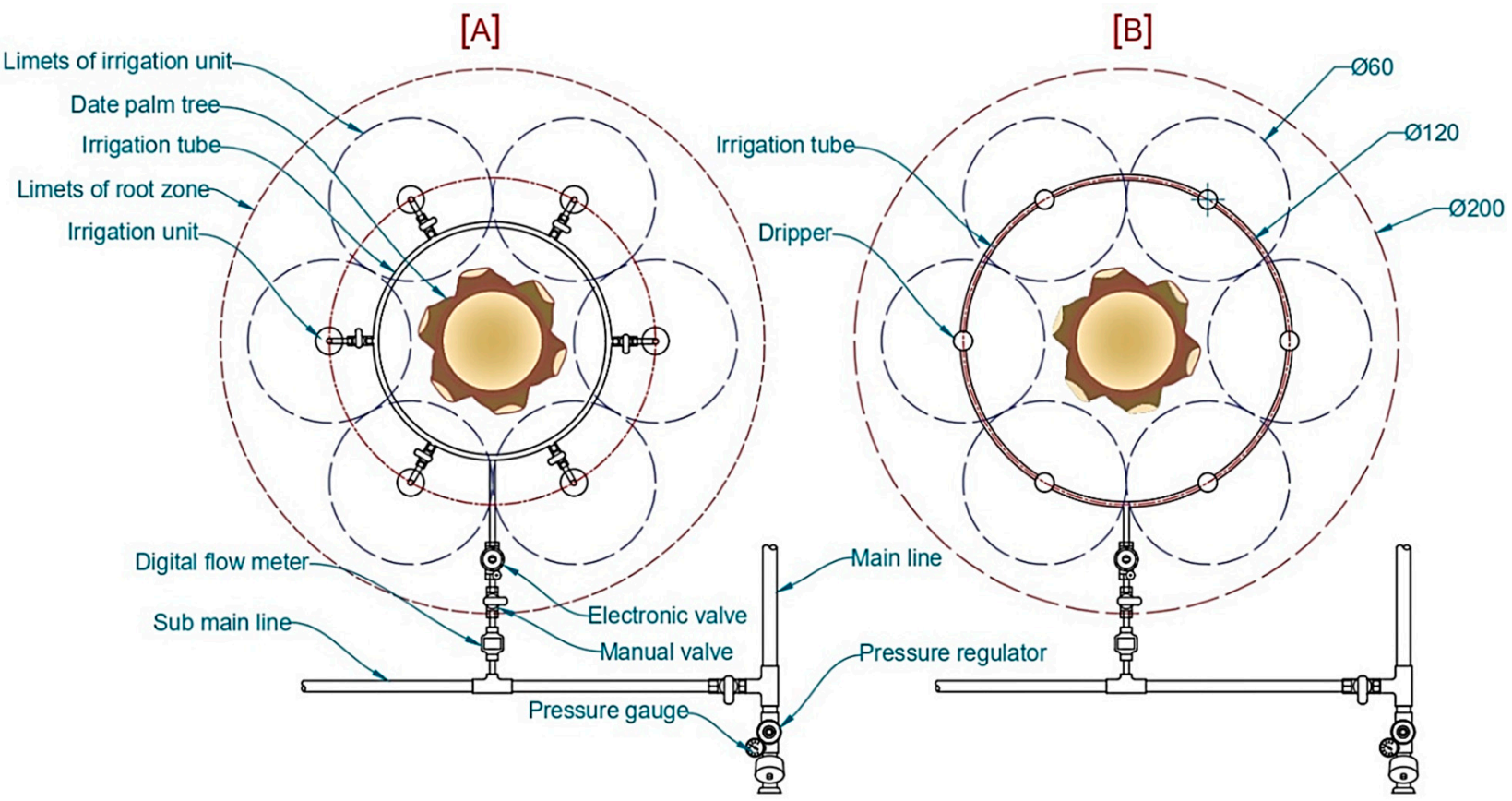

Figure 4. The main components of the surface irrigation system (A) and drip irrigation system (B). All dimensions are in centimeters.

In the traditional irrigation system (Control), three adjustable bubblers were used to deliver water to the same spot around the date palm tree. The average flow rate of the 
bubbler was $0.060 \mathrm{~m}^{3} \mathrm{~h}^{-1}$ at a pressure of $300 \mathrm{kPa}$. The water pressure was regulated using a pressure regulator. A $20 \mathrm{~cm}$ high and $180 \mathrm{~cm}$ diameter lateral line around each tree was created to prevent water runoff.

\subsection{IoT Monitoring and Controlling System}

A cloud-based IoT platform was established for monitoring meteorological variables and controlling the date palm irrigation schedule. The platform was included several parts, as shown in Figure 5. These parts are efficiently combined and seamlessly working to realize the monitoring and controlling objectives. The main components of the monitoring and controlling system were sensors, a microcontroller, a source of internet, a cloud-based platform, a user interface, and irrigation control devices. The temperature and relative humidity sensors (Model: DHT11, Guangzhou ASAIR Electronic Co., Ltd., Huangpu District, Guangzhou, China) were used to measure the air temperature and relative humidity in the study area. A cups-anemometer (Model: FST200-20, Hunan Firstrate Sensor Co., Ltd. Changsha, China) was used to measure the wind speed and direction. A solar cell calibrated by Mohammed et al. [41] (Photovoltaic solar module, monopoly 3 W, Flagsun (Suzhou) New Energy Co., Ltd., Suzhou, Jiangsu, China) was used for measuring solar radiation energy. The used microcontrollers were a module of Wi-Fi (ESP8266, NodeMCU, Shenzhen Quine Trading Co., Ltd., Shenzhen, Guangdong, China) and Arduino UNO board (Microchip ATmega328P, Microchip Technology Inc. W Chandler Blvd, Chandler, Arizona, USA). The internet was provided using a 4G Router (HUAWEI, Hunan JENET Technology Co., Ltd. Changsha, China) and a data SIM card of a local communications network. The internet module of NodeMCUs instantly has Wi-Fi access as soon as the SIM card is plugged in the router and turned on. The Ubidots cloud platform was used to monitor the meteorological variables data. The IFTTT (If This, Then That) tool was used as an automation tool that hooks various web services to help the user accomplish tasks. The automation is performed via applets, such as macros that connect multiple applications to run automated tasks. Applets can be turned on and off using the IFTTT website and mobile apps, which use IFTTT widgets, although it is possible to create one's own applets or make variations of existing ones via IFTTT's straightforward and user-friendly interface.

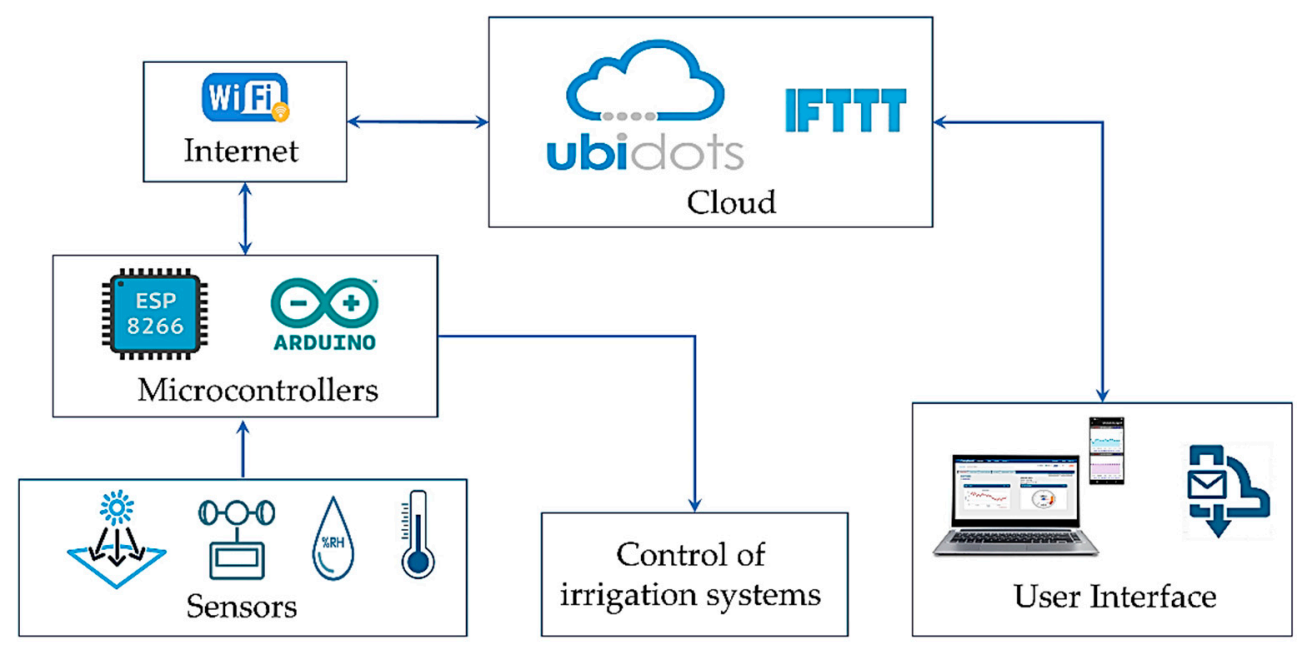

Figure 5. The main components of the cloud-based IoT platform, which was used to real-time monitor the meteorological variables in and control the irrigation water scheduling of the irrigation systems.

The sensors sent their collected data to the Arduino microcontroller in a real-time manner by the Wi-Fi module, which directly submits the collected data to the Ubidots platform. Therefore, the user accesses the real-time data through the 'graphical user interface' using the private channel on the Ubidots cloud platform. The Arduino UNO board and IFTTT interface were used for controlling the electronic relays of contactors, electronic valves, and irrigation pumps for scheduling the irrigation water of the irrigation 
systems. The irrigation pump and solenoid valve of the irrigation water was turned on or off based on the output signal of Arduino UNO. All real-time meteorology measurements in the research area are sent to the open-source Ubidots platform and FTTT interface. After connecting to the Ubidots platform and selecting a private channel to monitor the target parameters, the interface with real-time measurement results was reflected on a window display. The data were also stored in the cloud as Google spreadsheets, which were used for analysis and visualization of the parameters. Using this cloud-based platform, the user remotely monitors the farm and accesses its relevant meteorology data to decide the appropriate actions based on the current limits of the irrigation microcontroller. The IFTTT interface was compatible with the irrigation hardware by adding functions to control the irrigation valves and pump or sending the SMS messages to the user based on the action set by the user.

\subsection{Experimental Design}

The experiment involved two micro-irrigation systems of SI and DI with three deficit irrigation treatments, i.e., 50, 75, and 100\% of crop evapotranspiration (ETc). The two micro-irrigation systems were compared with a fully irrigated traditional surface bubbler irrigation system at $100 \%$ ETc (control). The experiment consisted of a two-factorial randomized block design. Factor-one was the three irrigation systems (SI, DI, and control), and factor-two was the three ETc levels $(50,75$, and 100\%). Six replicates of the control treatment (100\% ETc) were used for the comparison with the SI and DI systems, which had three replicates in each treatment (the combination of irrigation system and ETc levels). There were twenty-four date palm trees altogether.

The ETc was determined according to the following equation:

$$
\mathrm{ETc}=\mathrm{Kc} \times \mathrm{ETo}
$$

where ETc is the crop evapotranspiration $\left(\mathrm{mm} \mathrm{day}^{-1}\right), \mathrm{Kc}_{\mathrm{c}}$ is the crop factor, and ETo is the reference evapotranspiration ( $\mathrm{mm} \mathrm{day}^{-1}$, the average $\mathrm{Kc}$ was approximately 0.95) [42].

The ETo was determined based on the following Penman-Monteith equation [43]:

$$
\mathrm{ETo}=\frac{0.408 \Delta(\mathrm{R}-\mathrm{G})+\gamma[900 \mathrm{u} /(\mathrm{T}+273)]\left(\mathrm{e}_{\mathrm{s}}-\mathrm{e}_{\mathrm{a}}\right)}{\Delta+\gamma(1+0.34 \mathrm{u})}
$$

where ETo is the reference evapotranspiration $\left(\mathrm{mm} \mathrm{day}^{-1}\right)$ in the study area, $\mathrm{R}$ is the net solar radiation at the surface of the crop $\left(\mathrm{MJ} \mathrm{m}^{-2}\right.$ day $\left.{ }^{-1}\right), \mathrm{G}$ is the soil heat flux density $\left(\mathrm{MJ} \mathrm{m}{ }^{-2}\right.$ day $\left.^{-1}\right), \mathrm{T}$ is the temperature of atmospheric air $\left({ }^{\circ} \mathrm{C}\right), \mathrm{u}$ is the wind speed at $2 \mathrm{~m}$ height $\left(\mathrm{m} \mathrm{s}^{-1}\right), \mathrm{e}_{\mathrm{s}}$ is the saturation vapor pressure $(\mathrm{kPa}), \mathrm{e}_{\mathrm{a}}$ is the actual pressure of vapor $(\mathrm{kPa}), \Delta$ is the slope vapor pressure curve $\left(\mathrm{kPa}^{\circ} \mathrm{C}^{-1}\right)$, and $\gamma$ is the constant psychrometric $\left(\mathrm{kPa}{ }^{\circ} \mathrm{C}^{-1}\right)$.

The amount of irrigation water required was calculated per date palm tree as below:

$$
\mathrm{WR}=\mathrm{ETc} \times \mathrm{D}_{\mathrm{ip}} \times \mathrm{A}_{\mathrm{ti}}
$$

where WR is the amount of irrigation water required $\left(\mathrm{m}^{3}\right.$ day $\left.^{-1}\right)$, ETc is the crop evapotranspiration $\left(\mathrm{m} \mathrm{day}^{-1}\right), \mathrm{D}_{\mathrm{ip}}$ is the deficit irrigation percentage, and $\mathrm{A}_{\mathrm{ti}}$ is the target irrigation area of the date palm tree $\left(\mathrm{m}^{2}\right)$.

According to the FAO recommendations, the target irrigation area was calculated based on the light intercepted by the palm tree canopy as $80 \%$ of the actual shaded area of the palm tree [6]. 


\subsection{Measurements}

\subsubsection{Water Use Efficiency}

The water use efficiency was calculated using the following equation based on the date palm yield and the total volume of irrigation water:

$$
\mathrm{WUE}=\frac{\mathrm{Y}}{\mathrm{AW}}
$$

where WUE is water use efficiency $\left(\mathrm{kg} \mathrm{m}^{-3}\right), \mathrm{Y}$ is the yield of the date palm tree $(\mathrm{kg})$, and $\mathrm{AW}$ is the applied irrigation water for the same date palm tree $\left(\mathrm{m}^{3}\right)$.

\subsubsection{Chlorophyll Content and Gas Exchange}

The leaf chlorophyll content was estimated using a chlorophyll meter (SPAD 502, Konica-Minolta, Japan). The gas exchange (photosynthesis, stomatal conductance, transpiration, and intercellular $\mathrm{CO}_{2}$ concentration) under the different irrigation systems were estimated using the Li-Cor photosynthesis device (Li-6400XT LiCor Inc., Lincoln, NE, USA). The reference and sample $\mathrm{CO}_{2}$ of the Infra-Red Gas Analyzer was set at $400 \mu \mathrm{mol} \mathrm{m} \mathrm{s}^{-1}$ with $500 \mathrm{~mL} \mathrm{~min}^{-1}$ airflow. The data were taken from 11 o'clock in the morning in an open field under clear sky and ample sunshine. These parameters were recorded on the same dates in both years (2020-2021).

\subsubsection{Physiochemical Characteristics of Date Fruit}

The samples of date fruit after being harvested at the Tamar stage (full ripened stage, fruit color is brown) were randomly selected to determine their physicochemical characteristics. The fruit weights were measured using an electronic balance (Sartorius Lab Instruments $\mathrm{GmbH}$ and Co, Göttingen, Lower Saxony, Germany). Fruit length and diameter $(\mathrm{mm})$ were calculated with a digital Vernier caliper. The fruit total soluble solids (TSS), moisture content, and $\mathrm{pH}$ were determined according to standard AOAC analysis methods [44]. The fruit moisture content (\%) was measured by drying the samples under vacuum at $70{ }^{\circ} \mathrm{C}$ using a vacuum-drying oven (LabTech, LVO-2041P, Korea) [45-47]. The TSS was determined using a laboratory refractometer (RFM 860, Bellingham \& Stanley Ltd., Kent, UK). Fruit firmness $\left(\mathrm{N} \mathrm{mm}^{-2}\right.$ ) was determined by the Koehler penetrometer (K19900, Thomas Scientific, Swedesboro, NJ, USA) according to the methods described in [48]. Fruit color was recorded with the Hunter laboratory color difference meter (Quest-45/0 LAV, Hunter Associates Laboratory, Inc., Reston, USA) based on the $L, a$, and $b$ color system. Chroma and hue angle were also estimated using $a$ and $b$ readings.

\subsection{Statistical Analysis}

Data regarding the WUE, gas exchange, yield, and fruit characteristics of date palm trees were analyzed using a two-way ANOVA test to assess the effect of treatment and season, along with their interactions. The comparison between the irrigation systems was analyzed using the General Linear Models (GLM) Procedure of IBM SPSS 24 (SPSS Inc., Chicago, IL, USA). All means of the experiments were separated using Tukey's test at $5 \%$ probability.

\section{Results and Discussion}

\subsection{Meteorological Conditions and ETo}

Table 2 shows the observed monthly average values \pm standard deviation of the climatic variables and ETo of the experimental area using the designed cloud-based IoT platform. The highest average temperature was $37.52{ }^{\circ} \mathrm{C}$ during June to August, while the lowest average was $18.26^{\circ} \mathrm{C}$ during January, February, and December. The highest average relative humidity was $63.4 \%$ during December, while the lowest average relative humidity was 23.1\% during June. During August and July, the highest average sun hours and solar radiations were $10.4 \mathrm{~h}$ and $20.6 \mathrm{MJ} \mathrm{m}^{-2}$ day $^{-1}$, respectively. In June, the maximum average 
wind speed was $9.3 \mathrm{~km} \mathrm{~h}^{-1}$. The highest monthly average ETo was 9.19 and $9.43 \mathrm{~mm} \mathrm{day}^{-1}$ during June and July, respectively.

Table 2. Monthly average values \pm standard deviation of minimum temperature (Min Temp), maximum temperature (Max Temp), relative humidity (RH), wind speed (WS), sun hours (SH), solar radiation (Rad), and reference evapotranspiration (ETo) during the 2020-2021 seasons.

\begin{tabular}{|c|c|c|c|c|c|c|c|}
\hline \multirow[b]{2}{*}{ Months } & \multicolumn{6}{|c|}{ Meteorological Variables } & \multirow{2}{*}{$\begin{array}{c}\text { ETo } \\
\left(\mathrm{mm} \mathrm{day}^{-1}\right)\end{array}$} \\
\hline & $\begin{array}{l}\text { Min Temp } \\
\quad\left({ }^{\circ} \mathrm{C}\right)\end{array}$ & $\begin{array}{l}\text { Max Temp } \\
\left({ }^{\circ} \mathrm{C}\right)\end{array}$ & $\begin{array}{l}\text { RH } \\
(\%)\end{array}$ & $\begin{array}{c}\text { WS } \\
\left(\mathrm{km} \mathrm{day}^{-1}\right)\end{array}$ & $\begin{array}{l}\text { SH } \\
\text { (h) }\end{array}$ & $\underset{\left(\mathrm{MJ} \mathrm{m}^{-2} \text { day }^{-1}\right)}{\operatorname{Rad}}$ & \\
\hline January & $12.1 \pm 4.3$ & $26.1 \pm 3.2$ & $50.1 \pm 18.3$ & $8.24 \pm 1.8$ & $7.91 \pm 0.2$ & $15.2 \pm 0.7$ & $3.61 \pm 1.1$ \\
\hline February & $10.6 \pm 3.2$ & $25.2 \pm 1.9$ & $58.2 \pm 10.7$ & $6.32 \pm 2.4$ & $8.14 \pm 0.1$ & $17.5 \pm 0.6$ & $4.71 \pm 1.2$ \\
\hline March & $12.9 \pm 4.6$ & $28.2 \pm 2.8$ & $49.9 \pm 12.6$ & $7.23 \pm 1.6$ & $8.51 \pm 0.1$ & $21.1 \pm 0.7$ & $5.95 \pm 1.3$ \\
\hline April & $19.1 \pm 3.2$ & $32.6 \pm 3.3$ & $48.3 \pm 16.5$ & $8.11 \pm 1.4$ & $8.69 \pm 0.1$ & $21.9 \pm 0.8$ & $6.41 \pm 1.1$ \\
\hline May & $24.9 \pm 3.1$ & $42.1 \pm 3.1$ & $30.2 \pm 12.4$ & $7.32 \pm 1.5$ & $8.99 \pm 0.2$ & $23.8 \pm 0.5$ & $8.82 \pm 1.4$ \\
\hline June & $27.5 \pm 2.1$ & $47.9 \pm 2.4$ & $28.4 \pm 15.2$ & $8.31 \pm 1.3$ & $8.57 \pm 0.2$ & $24.7 \pm 0.4$ & $9.28 \pm 1.0$ \\
\hline July & $29.8 \pm 1.8$ & $48.3 \pm 3.2$ & $29.3 \pm 18.2$ & $8.21 \pm 1.6$ & $9.99 \pm 0.2$ & $25.6 \pm 0.3$ & $9.55 \pm 1.5$ \\
\hline August & $29.7 \pm 2.1$ & $47.8 \pm 2.4$ & $33.1 \pm 17.1$ & $7.99 \pm 2.1$ & $9.89 \pm 0.1$ & $25.3 \pm 0.6$ & $8.99 \pm 1.6$ \\
\hline September & $27.1 \pm 1.8$ & $44.9 \pm 2.2$ & $41.8 \pm 16.4$ & $7.65 \pm 1.7$ & $9.87 \pm 0.2$ & $22.6 \pm 0.8$ & $8.64 \pm 1.3$ \\
\hline
\end{tabular}

\subsection{Actual Cumulative Applied Irrigation Water}

The amount of applied irrigation water was calculated as a percentage of the ETc, Kc, and the target irrigation area of the date palm tree. The average Kc value for the date palm during the productive cycle was 0.95 . The average target irrigation area of the tested date palm tree was $25.52 \pm 3.37 \mathrm{~m}^{2}$. There was no significant variation in the average values of actual water applied per palm between the irrigation systems of SI, DI, and control. The average amount of the actual cumulative applied irrigation water during the 2020-2021 seasons at the irrigation treatments of 50, 75, and $100 \%$ ETc were $27.28 \pm 0.06,44.14 \pm 1.07$, and $55.55 \pm 0.37 \mathrm{~m}^{3}$ palm ${ }^{-1}$, respectively, as shown in Figure 6 .

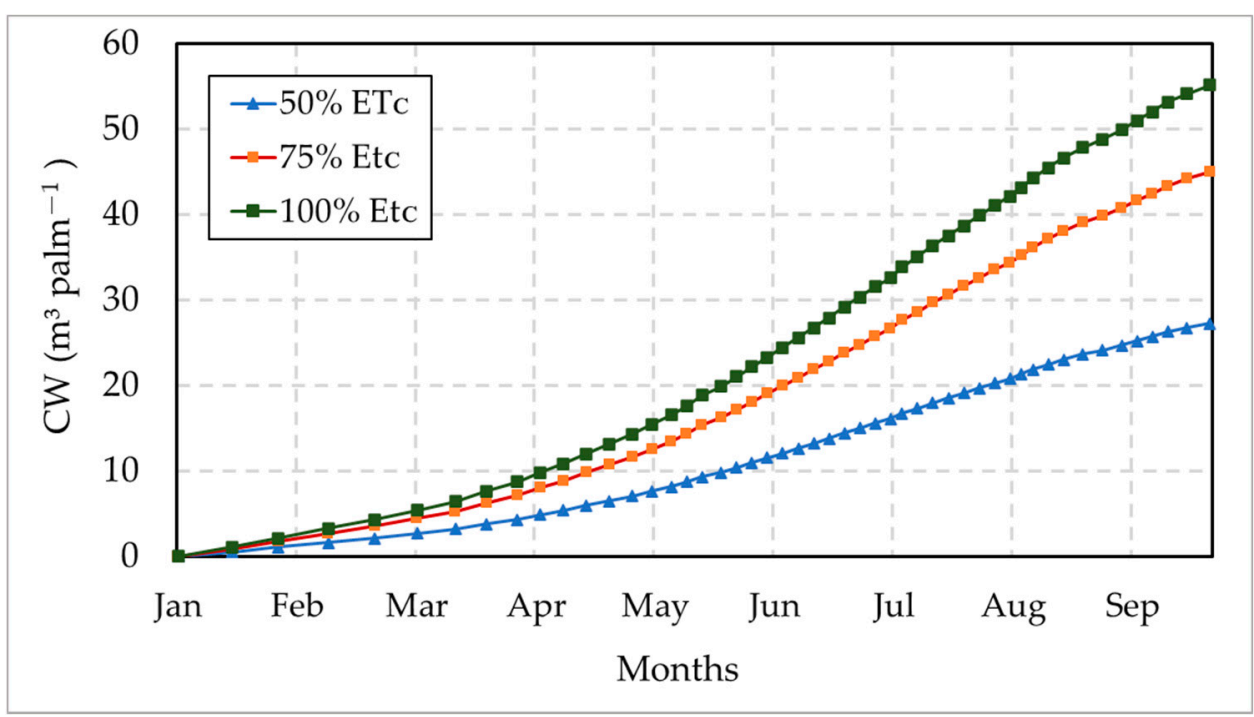

Figure 6. The average amount of the actual cumulative applied water $(\mathrm{CW})$ per palm under the various irrigation treatments of 50,75, and 100\% ETc during the 2020-2021 seasons.

\subsection{Chlorophyll Content and Gas Exchange}

Results regarding chlorophyll content indicated a significant year-round variation among different watered by micro-irrigation systems (Table 3 and Figure 7). Date palm (Khalas cv.) irrigated at 100\% ETc in the SI system had the highest chlorophyll content and was statistically at par with the control (100\% ETc). However, the chlorophyll content 
at 50,75 , and $100 \%$ ETc was significantly higher in the SI system compared to the DI system. The significantly lowest chlorophyll content at all water regimes was observed in the DI system throughout the experimental period. The decrease in chlorophyll content could be due to an increase in electrolyte leakage due to leaf senescence [49], which was negatively influenced by the decreased in water [50]. In the present study, the SI and control bubbler irrigation system enhanced chlorophyll content at the expense of increased water availability at a $100 \%$ ETc level. Water could be saved by adopting efficient irrigation systems such as SI at 75 and $50 \%$ ETc, with only a minor reduction in leaf chlorophyll content. A similar response was observed in the date palm (Sheshi cv.), where chlorophyll content was increased in the SI system [3]. The decrease in chlorophyll content in the DI system under deficit water conditions could be attributable to the fact that water stress impeded the photophosphorylation process, which converts light energy into chemical energy, and therefore, the end product chlorophyll was reduced [51].

Table 3. The average values of two years of data of physiological parameters of date palm Khalas cv. under the two irrigation systems (DI and SI) at three ETc levels (50, 75, and 100\%) compared with the bubbler irrigation system (control) at $100 \%$ ETc.

\begin{tabular}{|c|c|c|c|c|c|c|}
\hline $\begin{array}{l}\text { Irrigation } \\
\text { Systems }\end{array}$ & $\%$ ETc & $\begin{array}{l}\text { Chlorophyll } \\
\text { (SPAD) }\end{array}$ & $\begin{array}{l}\text { Photosynthesis } \\
\qquad(\mu \mathrm{mol} \mathrm{CO} 2 \\
\left.\mathrm{m}^{-2} \mathrm{~s}^{-1}\right)\end{array}$ & $\begin{array}{c}\text { Stomatal } \\
\text { Conductance } \\
\left(\mathrm{mol} \mathrm{H}_{2} \mathrm{O} \mathrm{m}^{-2} \mathrm{~s}^{-1}\right)\end{array}$ & $\begin{array}{c}\text { Transpiration } \\
\left(\mathrm{mmol} \mathrm{H}_{2} \mathrm{O}\right. \\
\left.\mathrm{m}^{-2} \mathrm{~s}^{-1}\right)\end{array}$ & $\begin{array}{c}\text { Inter. } \mathrm{CO}_{2} \text { Conc. } \\
\left(\mu \mathrm{mol} \mathrm{CO} \mathrm{mol}^{-1}\right)\end{array}$ \\
\hline Control & 100 & $62.04^{\mathrm{a}} \pm 6.03$ & $13.52^{\mathrm{a}} \pm 2.45$ & $0.059^{\mathrm{a}} \pm 0.009$ & $1.391^{\mathrm{a}} \pm 0.41$ & $149.5^{\mathrm{cd}} \pm 15.7$ \\
\hline \multirow{3}{*}{ SI } & 50 & $55.91^{b} \pm 5.38$ & $13.16^{\mathrm{a}} \pm 2.45$ & $0.052^{b d} \pm 0.01$ & $1.193^{\mathrm{ab}} \pm 0.33$ & $158.9^{\mathrm{bd}} \pm 17.1$ \\
\hline & 75 & $58.55^{\mathrm{ab}} \pm 6.12$ & $13.41^{\mathrm{a}} \pm 2.16$ & $0.049^{\text {ce }} \pm 0.01$ & $1.223^{\mathrm{ab}} \pm 0.33$ & $164.5^{\mathrm{ac}} \pm 17.8$ \\
\hline & 100 & $62.69^{a} \pm 5.89$ & $13.39^{\mathrm{a}} \pm 2.2 .17$ & $0.053^{\mathrm{ad}} \pm 0.01$ & $1.392^{\mathrm{a}} \pm 0.37$ & $169.8^{\mathrm{ab}} \pm 23.3$ \\
\hline \multirow{3}{*}{ DI } & 50 & $45.81^{\mathrm{c}} \pm 10.43$ & $8.66^{c} \pm 2.19$ & $0.039^{f} \pm 0.007$ & $0.962^{b} \pm 0.22$ & $178.2^{a} \pm 26.6$ \\
\hline & 75 & $47.54^{\mathrm{c}} \pm 9.11$ & $9.34^{\mathrm{c}} \pm 1.74$ & $0.044^{\text {ef }} \pm 0.01$ & $0.952^{b} \pm 0.21$ & $165.9^{\mathrm{ab}} \pm 23.7$ \\
\hline & 100 & $55.64^{b} \pm 5.56$ & $11.21^{\mathrm{b}} \pm 2.06$ & $0.047^{\text {de }} \pm 0.01$ & $1.231^{\mathrm{ab}} \pm 0.23$ & $169.8^{\mathrm{ab}} \pm 22.9$ \\
\hline
\end{tabular}

Data with identical letter(s) within each parameter are non-significant statistically at a $5 \%$ probability level. The average leaf temperature was $27.78 \pm 0.75^{\circ} \mathrm{C}$.

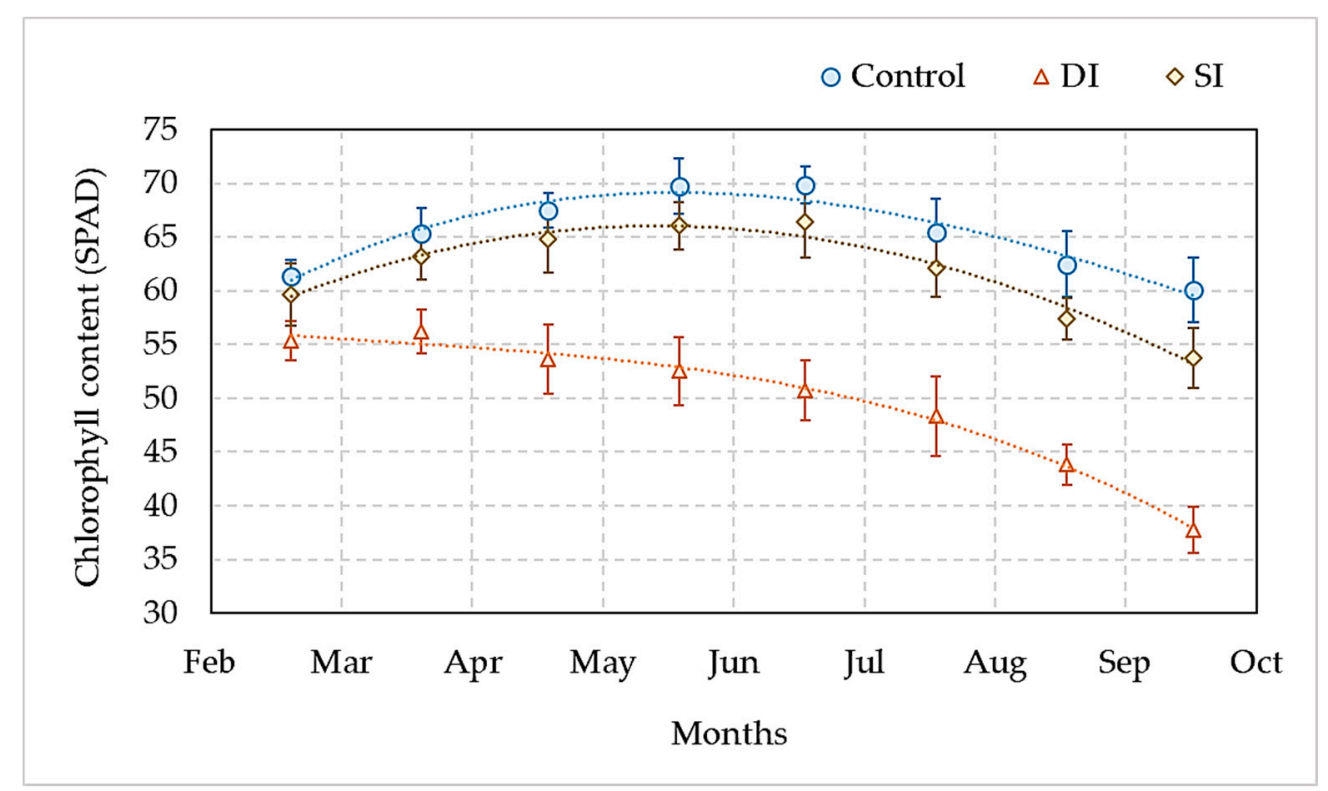

Figure 7. Effect of drip irrigation (DI), subsurface irrigation (SI), and bubbler irrigation (control) systems on chlorophyll content of date palm (Khalas cv.). Each data point for SI and DI systems represents an average of 50,75, and 100\% ETc levels, whereas it is at 100\% ETc level for control during 2020-2021. 
Variations in plant water application rates have a substantial impact on plant development and other physiological processes. The data presented in Table 3 indicate significant differences in gas exchange parameters under the different irrigation systems and water deficit levels. The data presented are the average of two years because the interaction between the treatment and season was non-significant statistically. At all ETc levels where sufficient water was applied (control), photosynthesis, stomatal conductance, and transpiration were significantly higher. These variables followed a similar pattern in the SI system throughout all water deficit levels, whereas they were significantly lower in the DI system. Intercellular $\mathrm{CO}_{2}$ concentration declined linearly from higher ETc to lower ETc as photosynthesis, stomatal conductance, and transpiration values increased. Similarly, the values of photosynthesis, stomatal conductance, and transpiration were lower during spring and winter months, whereas these values were higher during summertime (Figures 8-10). Intercellular $\mathrm{CO}_{2}$ concentrations, on the other hand, showed an opposite response, with higher levels in the spring and winter months and lower levels in the summer (Figure 11). To compensate for water loss and preserve their hydric condition, plants adapt to water stress by producing morpho-anatomical, physiological, and biochemical changes [52]. Many crops have shown a decrease in photosynthesis when exposed to water stress [53], which can be attributed to a drop in $\mathrm{CO}_{2}$ assimilation as stomata close or photo-oxidation impairs the photosynthetic mechanism [54]. Deficit water causes stomata to close, altering plant photosynthetic activity and lowering the $\mathrm{CO}_{2} / \mathrm{O}_{2}$ ratio in leaves $[55,56]$. To prevent water loss through transpiration, certain plants lower their stomatal conductance, which reduces $\mathrm{CO}_{2}$ assimilation [57]. Water stress induced a significant reduction in photosynthetic rates, stomatal conductance, and transpiration rates in date palm cultivars [58]. In an in vitro study, Helaly and El-Hosieny [35] found that water stress reduced the photosynthetic rate, stomatal conductance, and transpiration rate in date palm cvs. Shamia and Amri. Similarly, when water stress increases, the photosynthetic rate becomes more dependent on intercellular $\mathrm{CO}_{2}$ concentration, according to Onoda et al. [59]. The present findings agreed with these studies, as higher stomatal conductance resulted in a higher net photosynthetic rate, and deficit water applied in the DI system negatively affected these variables. Low temperatures in the winter have been reported to reduce root permeability and plant hydraulic conductance, resulting in lower stomatal conductance [60]. It supports the present findings regarding the year-round variation in the photosynthetic system (Figures 8-11).

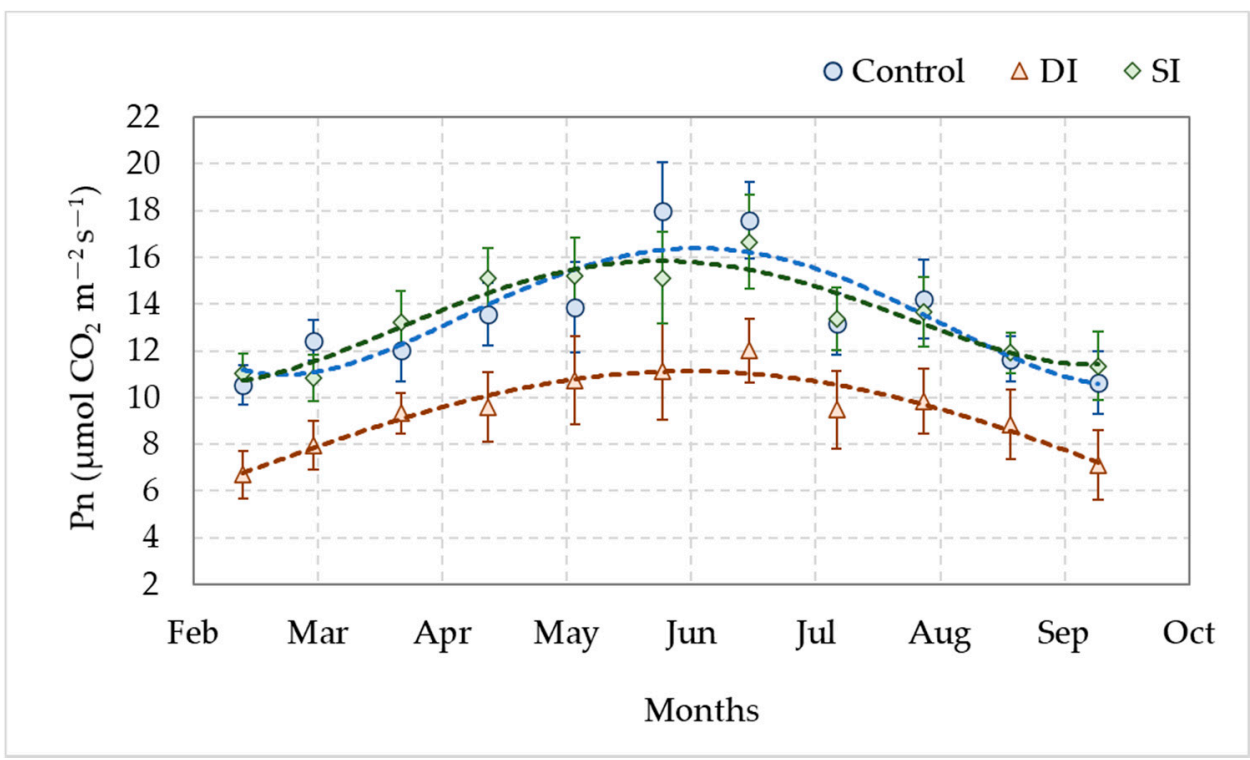

Figure 8. Effect of drip irrigation (DI), subsurface irrigation (SI), and bubbler irrigation (control) systems on photosynthesis (Pn) of date palm (Khalas cv.). Each data point for SI and DI systems represents an average of 50, 75, and 100\% ETc levels, whereas it is at 100\% ETc level for control during 2020-2021. 


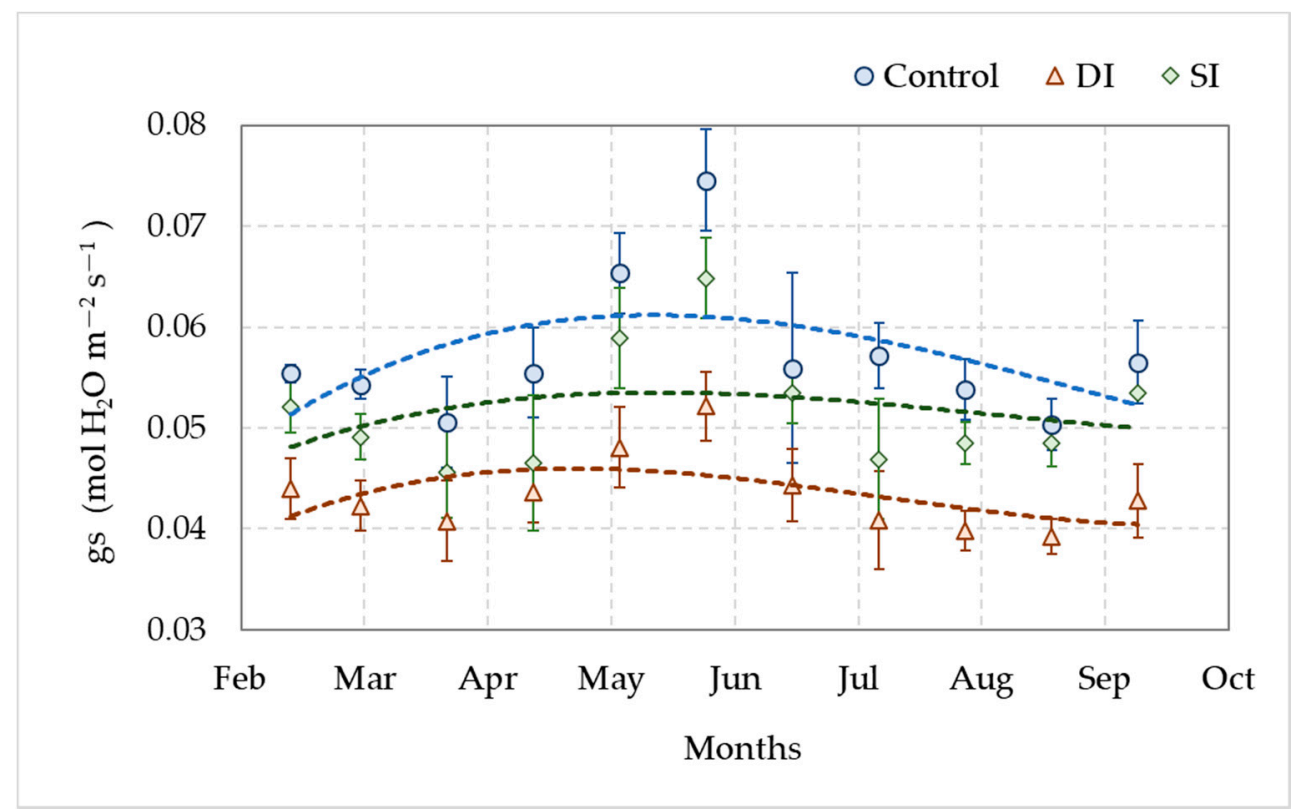

Figure 9. Effect of drip irrigation (DI), subsurface irrigation (SI), and bubbler irrigation (control) systems on stomatal conductance (gs) of date palm (Khalas cv.). Each data point for SI and DI systems represents an average of 50, 75, and $100 \%$ ETc levels, whereas it is at $100 \%$ ETc level for control during 2020-2021.

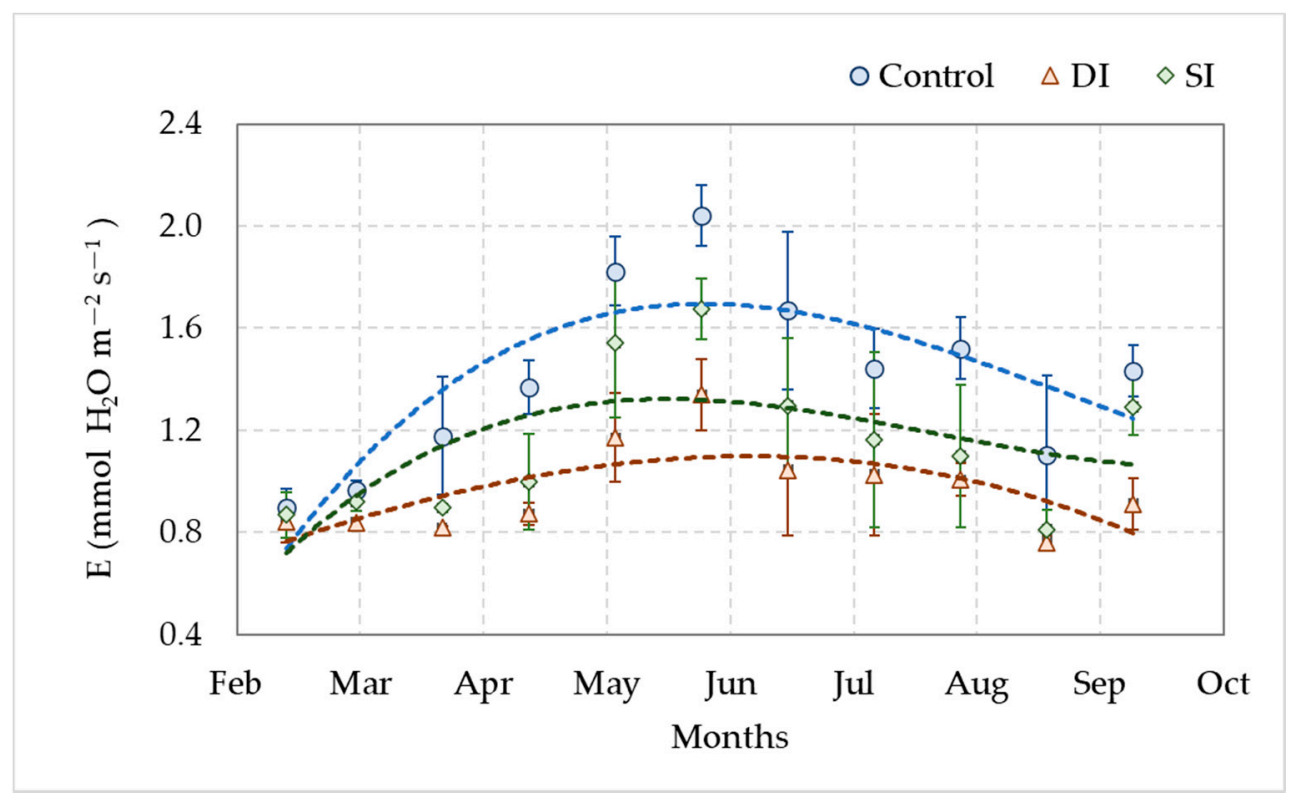

Figure 10. Effect of drip irrigation (DI), subsurface irrigation (SI), and bubbler irrigation (control) systems on transpiration rate (E) of date palm (Khalas cv.). Each data point for SI and DI systems represents an average of 50, 75, and 100\% ETc levels, whereas it is at 100\% ETc level for control during 2020-2021. 


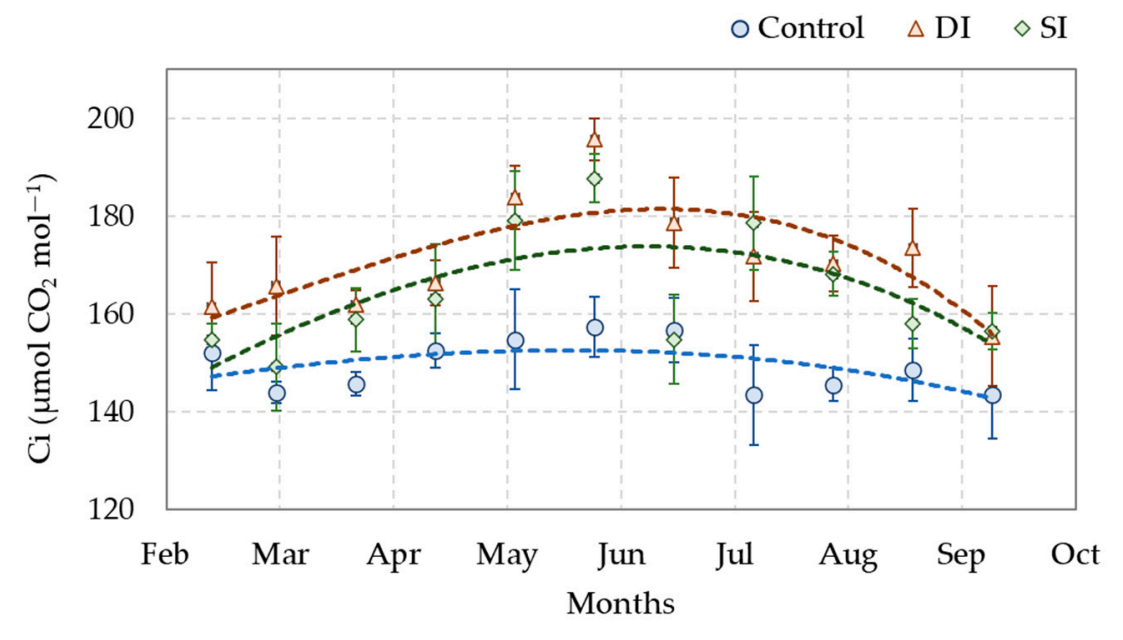

Figure 11. Effect of drip irrigation (DI), subsurface irrigation (SI), and bubbler irrigation (control) systems on the intercellular $\mathrm{CO}_{2}$ concentration ( $\mathrm{Ci}$ ) of date palm (Khalas cv.). Each data point for SI and DI systems represents an average of 50,75, and 100\% ETc levels, whereas it is at 100\% ETc level for control during 2020-2021.

\subsection{Yield and Water Use Efficiency}

Table 4 shows the amount of yield per palm and WUE of date palm (Khalas cv.) under irrigation systems (DI, SI, and Control). There was no interactive effect between treatment and season. In the SI system, the yield per palm and WUE were significantly improved at all ETc levels. The increased yield of palm trees could be related to the optimal availability of soil water, which promotes balanced root growth and nutrient uptake in the soil $[61,62]$. The yield per tree and WUE results are in agreement with $[27,30,63]$. In the DI system, the WUE was lower, but in the SI system, it was higher. It could be because the SI system might reduce water runoff and decrease water loss due to evaporation. Therefore, water was available within the functional root system, which was efficiently utilized by the palm in the synthesis of photosynthates, resulting in increased fruit production $[3,14]$.

Table 4. The average values of two years of data \pm standard deviation of yield per palm and water use efficiency of date palm Khalas cv. under the two irrigation systems (DI and SI) at three Etc levels $(50,75$, and $100 \%)$ compared with the bubbler irrigation system (control) at $100 \%$ ETc.

\begin{tabular}{cccc}
\hline $\begin{array}{c}\text { Irrigation } \\
\text { Systems }\end{array}$ & \% ETc & $\begin{array}{c}\text { Yield } \\
\mathbf{( k g ~ p a l m ~}^{-1} \mathbf{)}\end{array}$ & $\begin{array}{c}\text { Water Use Efficiency } \\
\mathbf{( k g ~ m}^{-3} \mathbf{~}\end{array}$ \\
\hline Control & 100 & $32.41^{\mathrm{ab}} \pm 3.06$ & $0.59^{\mathrm{c}} \pm 0.05$ \\
\hline \multirow{2}{*}{ SI } & 50 & $29.87^{\mathrm{b}} \pm 4.51$ & $1.09^{\mathrm{a}} \pm 0.15$ \\
& 75 & $39.40^{\mathrm{a}} \pm 0.87$ & $0.88^{\mathrm{ab}} \pm 0.03$ \\
& 100 & $39.03^{\mathrm{a}} \pm 2.93$ & $0.71^{\mathrm{bc}} \pm 0.05$ \\
\hline \multirow{2}{*}{ DI } & 50 & $14.23^{\mathrm{c}} \pm 2.05$ & $0.52^{\mathrm{cd}} \pm 0.08$ \\
& 75 & $26.50^{\mathrm{b}} \pm 4.27$ & $0.62^{\mathrm{c}} \pm 0.13$ \\
& 100 & $32.13^{\mathrm{ab}} \pm 3.96$ & $0.59^{\mathrm{c}} \pm 0.08$ \\
\hline
\end{tabular}

Data with identical letter(s) within each parameter are non-significant statistically at a $5 \%$ probability level.

\subsection{Fruit Quality}

When the 50\% ETc values of the SI system were compared to the $100 \%$ ETc values of the control, there was a statistically non-significant difference in all fruit quality attributes (fruit weight, length and width, pulp weight, firmness, moisture content, fruit pH, TSS, and fruit color) (Table 5). However, there was a significant difference in the values of these variables when the SI and DI systems were compared. The difference between the two 
years was non-significant statistically. The efficient consumption of water within the date palm tree's functional absorbing root zone in the SI system might be attributed to reduced water runoff and evaporation at 50\% ETc [64,65], which also improves the uptake of plant nutrients [61,66,67]. Although water stress negatively affects fruit weight and size [68], as seen in the DI system at 50\% ETc, such an adverse effect was not observed in the SI system at $50 \%$ ETc. This may correlate with the lack of evaporation and abundant availability of water at the functional root zone of the palm provided by the SI system. The current findings are similar to the date palm cv. Mazafati, whose physical qualities (fruit size, weight, and firmness) were improved by reducing irrigation water [30]. The fruit TSS and pH of date palm (Khalas cv.) did not differ significantly between water stress treatments [69]. Similarly, in date palm cv. Mazafati, the significant effect on TSS was attributed to location rather than water stress [30]. Their results confirm the findings of the present study, where fruit TSS and $\mathrm{pH}$ was not significantly affected by water regimes. As the harvest time is judged based on the surface color of the date palm fruit, the present results indicated a non-significant effect of different irrigation systems and water regimes on fruit color metrics except fruit lightness. Since it is well known that light significantly induces fruit color in apple and pear [70] while high temperature inhibits it in strawberry [71], therefore, in the present study, water stress did not promote or suppress fruit color.

Table 5. The average values of two years of data \pm standard deviation of physiochemical properties of date palm (Khalas cv.) recorded at the Tamar stage in drip irrigation (DI) and subsurface irrigation (SI) systems at 50\% ETc compared with the bubbler irrigation system (control) at $100 \%$ ETc.

\begin{tabular}{|c|c|c|c|}
\hline \multirow[b]{2}{*}{ Fruit Characteristics } & \multicolumn{3}{|c|}{ Irrigation Treatments } \\
\hline & $\begin{array}{c}\text { DI } \\
(50 \% \text { ETc })\end{array}$ & $\begin{array}{c}\text { SI } \\
(50 \% \text { ETc })\end{array}$ & $\begin{array}{c}\text { Control } \\
(100 \% \text { ETc })\end{array}$ \\
\hline Fruit weight (g) & $7.13^{b} \pm 0.41$ & $9.31^{\mathrm{a}} \pm 0.33$ & $9.55^{\mathrm{a}} \pm 0.56$ \\
\hline Fruit length (mm) & $31.2^{c} \pm 0.30$ & $36.2^{\mathrm{a}} \pm 0.34$ & $37.9^{a} \pm 0.43$ \\
\hline Fruit diameter (mm) & $23.3^{b} \pm 0.11$ & $24.3^{\mathrm{a}} \pm 0.12$ & $24.8^{\mathrm{a}} \pm 0.21$ \\
\hline Pulp weight (g) & $6.51^{\mathrm{b}} \pm 0.21$ & $7.51^{\mathrm{a}} \pm 0.16$ & $7.89^{\mathrm{a}} \pm 0.23$ \\
\hline Firmness $\left(\mathrm{N} \mathrm{mm}^{-2}\right)$ & $6.38^{b} \pm 0.29$ & $2.98^{\mathrm{a}} \pm 0.56$ & $2.90^{\mathrm{a}} \pm 0.32$ \\
\hline Moisture content (\%) & $12.6^{b} \pm 0.12$ & $13.6^{\mathrm{a}} \pm 0.66$ & $14.1^{\mathrm{a}} \pm 0.54$ \\
\hline Fruit $\mathrm{pH}$ & $6.8^{\mathrm{a}} \pm 0.21$ & $6.8^{\mathrm{a}} \pm 0.14$ & $6.67^{\mathrm{a}} \pm 0.23$ \\
\hline TSS ('Brix) & $62.9^{\mathrm{a}} \pm 0.16$ & $62.9^{\mathrm{a}} \pm 0.24$ & $62.1^{\mathrm{a}} \pm 0.23$ \\
\hline L (Lightness) & $34.9^{b} \pm 2.2$ & $44.9^{\mathrm{a}} \pm 3.2$ & $44.2^{\mathrm{a}} \pm 3.8$ \\
\hline$a$ (Greenness-redness) & $12.5^{\mathrm{a}} \pm 1.2$ & $12.5^{\mathrm{a}} \pm 3.2$ & $12.3^{\mathrm{a}} \pm 2.3$ \\
\hline$b$ (Blueness-yellowness) & $19.6^{\mathrm{a}} \pm 2.1$ & $19.6^{\mathrm{a}} \pm 3.9$ & $20.5^{\mathrm{a}} \pm 3.8$ \\
\hline Hue angle & $59^{\mathrm{a}} \pm 3.6$ & $59.3^{\mathrm{a}} \pm 5.2$ & $59.5^{\mathrm{a}} \pm 6.3$ \\
\hline Chroma & $23.1^{\mathrm{a}} \pm 4.1$ & $23.1^{\mathrm{a}} \pm 4.6$ & $23.9^{\mathrm{a}} \pm 5.1$ \\
\hline
\end{tabular}

Data with identical letter(s) within each parameter are non-significant statistically at a 5\% probability level.

\section{Conclusions}

In arid regions, the water scarcity issue is becoming more common. Crops with the ability to tolerate water stress while maintaining consistent growth and yielding performance have a clear advantage. This study evaluated two micro-irrigation systems: subsurface irrigation (SI) and drip irrigation (DI) under different water regimes (50, 75, and $100 \%$ ETc) in order to conserve irrigation water in date palm farming in water-scarce regions. This was done by comparing the SI and DI systems with a conventional surface irrigation system (fully irrigated bubbler irrigation system). Using the SI micro-irrigation system with deficit irrigation of 50\% ETc solved the problems of harsh climate and higher temperature for most of the year. The results revealed that applying the SI system with 50\% ETc maintained the economic yield and fruit quality of date palm (Khalas cv.) compared with DI and traditional irrigation methods at $100 \%$ ETc. In terms of WUE, the SI system had the highest value $\left(1.09 \mathrm{~kg} \mathrm{~m}^{-3}\right)$ compared with the DI $\left(0.52 \mathrm{~kg} \mathrm{~m}^{-3}\right)$ at $50 \%$ ETc deficit irrigation water and a traditional irrigation system $\left(0.59 \mathrm{~kg} \mathrm{~m}^{-3}\right)$ at $100 \%$ ETc. Future studies could focus on integrated water-saving technologies that combine the SI system, 
such as soil moisture and leaf temperature sensors, to help date palm growers make better irrigation decisions. The current study paved the way for further investigations under different environmental conditions in particular soil and other crops species.

Author Contributions: Conceptualization, M.M. (Maged Mohammed), A.S., M.M. (Muhammad Munir), and H.A.-D.; methodology, M.M. (Maged Mohammed) and M.M. (Muhammad Munir); engineering design, M.M. (Maged Mohammed); software, M.M. (Maged Mohammed); system manufacturing, M.M. (Maged Mohammed); validation, M.M. (Maged Mohammed) and M.M. (Muhammad Munir); formal analysis, M.M. (Maged Mohammed); investigation, M.M. (Maged Mohammed), A.S., M.M. (Muhammad Munir), and H.A.-D.; data curation, M.M. (Maged Mohammed); writing—original draft preparation, M.M. (Maged Mohammed) and M.M. (Muhammad Munir); writing-review and editing, M.M. (Maged Mohammed), A.S., M.M. (Muhammad Munir), and H.A.-D.; visualization, M.M. (Maged Mohammed); project administration, M.M. (Maged Mohammed); funding acquisition, M.M. (Maged Mohammed) All authors have read and agreed to the published version of the manuscript.

Funding: This study has been funded by Date Palm Research Center of Excellence, King Faisal University, Saudi Arabia, through funding the research project number DPRC-1-2020.

Institutional Review Board Statement: Not applicable.

Informed Consent Statement: Not applicable.

Data Availability Statement: Not applicable.

Acknowledgments: The authors appreciate the financial support and the availability of the engineering workshops and experimental date palm fields for conducting this study by the Date Palm Research Center of Excellence (DPRC), King Faisal University, Saudi Arabia. Moreover, the authors acknowledge Walid Al-Senain and Mubarak Al-Mawaid for their technical assistance in the DPRC laboratory and farmworkers at the center for their help in the implementation of this study in the field.

Conflicts of Interest: All authors declare no conflict of interest.

\section{References}

1. IPCC. Intergovernmental Panel on Climate Change. Impacts, Adaptation, and Vulnerability: Contribution of working group II to the fifth assessment report of the Intergovernmental Panel on Climate Change. Intergov. Panel Clim. Chang. 2014, 1, 1-44. [CrossRef]

2. Askri, B.; Ahmed, A.T.; Abichou, T.; Bouhlila, R. Effects of shallow water table, salinity and frequency of irrigation water on the date palm water use. J. Hydrol. 2014, 513, 81-90. [CrossRef]

3. Mohammed, M.; Alhajhoj, M.R.; Ali-Dinar, H.M.; Munir, M. Impact of a novel water-saving subsurface irrigation system on water productivity, photosynthetic characteristics, yield, and fruit quality of date palm under arid conditions. Agronomy 2020, 10, 1265. [CrossRef]

4. De Wrachien, D.; Schultz, B.; Goli, M.B. Impacts of population growth and climate change on food production and irrigation and drainage needs: A world-wide view*. Irrig. Drain. 2021, 1-15. [CrossRef]

5. Sagheer, A.; Mohammed, M.; Riad, K.; Alhajhoj, M. A cloud-based IoT platform for precision control of soilless greenhouse cultivation. Sensors 2021, 21, 223. [CrossRef] [PubMed]

6. FAO. Water for Sustainable Food and Agriculture Water for Sustainable Food and Agriculture. Rep. Prod. G20 Pres. Ger. 2017, 10-15. Available online: http://www.fao.org/3/i7959e/i7959e.pdf (accessed on 4 September 2021).

7. Calzadilla, A.; Rehdanz, K.; Tol, R.S.J. Water scarcity and the impact of improved irrigation management: A computable general equilibrium analysis. Agric. Econ. 2011, 42, 305-323. [CrossRef]

8. Ballester, C.; Zarco-Tejada, P.J.; Nicolás, E.; Alarcón, J.J.; Fereres, E.; Intrigliolo, D.S.; Gonzalez-Dugo, V. Evaluating the performance of xanthophyll, chlorophyll and structure-sensitive spectral indices to detect water stress in five fruit tree species. Precis. Agric. 2018, 19, 178-193. [CrossRef]

9. Gonzales-Gustavson, E.; Rusiñol, M.; Medema, G.; Calvo, M.; Girones, R. Quantitative risk assessment of norovirus and adenovirus for the use of reclaimed water to irrigate lettuce in Catalonia. Water Res. 2019, 153, 91-99. [CrossRef] [PubMed]

10. Martínez-Alvarez, V.; Martin-Gorriz, B.; Soto-García, M. Seawater desalination for crop irrigation-A review of current experiences and revealed key issues. Desalination 2016, 381, 58-70. [CrossRef]

11. FAOSTAT. Food and Agriculture Organization of the United Nations. 2019. Available online: http://faostat.fao.org/site. (accessed on 29 September 2021). 
12. Dhehibi, B.; Ben Salah, M.; Frija, A. Date Palm Value Chain Analysis and Marketing Opportunities for the Gulf Cooperation Council (GCC) Countries. In Agricultural Economics-Current Issues; Kulshreshtha, S.N., Ed.; IntechOpen: Rijeka, Kvarner, Croatia, 2019. [CrossRef]

13. Liebenberg, P.J.; Zaid, A. Date palm irrigation. In Date Palm Cultivation; Zaid, A., Arias-Jiménez, E.J., Eds.; Food and Agricultural Organization of the United Nations: Rome, Italy, 2002; Volume 156. [CrossRef]

14. Mohammed, M.; Riad, K.; Alqahtani, N. Efficient iot-based control for a smart subsurface irrigation system to enhance irrigation management of date palm. Sensors 2021, 21, 3942. [CrossRef]

15. Carr, M.K.V. Advances in Irrigation Agronomy; Cambridge University Press: Cambridge, UK, 2014. [CrossRef]

16. Zaid, A.; Arias-Jiménez, E.J. Date Palm Cultivation; Food and Agriculture Organization (FAO): Rome, Italy, 1999.

17. Food and Agriculture Organization of the United (FAO) \& International Center for Advanced Mediterranean Agro-nomic Studies (CIHEAM). In Workshop on "Irrigation of Date Palm and Associated Crops"; Faculty of Agriculture, Damascus University: Damascus, Syrian Arab Republic, 2008; ISBN 9789251059975.

18. Amira, E.A.; Flamini, G.; Behija, S.E.; Manel, I.; Nesrine, Z.; Ali, F.; Mohamed, H.; Noureddine, H.A.; Lotfi, A. Chemical and aroma volatile compositions of date palm (Phoenix dactylifera L.) fruits at three maturation stages. Food Chem. 2011, 127, 1744-1754. [CrossRef]

19. Kashyap, P.K.; Kumar, S.; Jaiswal, A.; Prasad, M.; Gandomi, A.H. Towards Precision Agriculture: IoT-enabled Intelligent Irrigation Systems Using Deep Learning Neural Network. IEEE Sens. J. 2021, 21, 17479-17491. [CrossRef]

20. Liao, R.; Zhang, S.; Zhang, X.; Wang, M.; Wu, H.; Zhangzhong, L. Development of smart irrigation systems based on real-time soil moisture data in a greenhouse: Proof of concept. Agric. Water Manag. 2021, 245, 106632. [CrossRef]

21. Calera, A.; Campos, I.; Osann, A.; D’Urso, G.; Menenti, M. Remote sensing for crop water management: From ET modelling to services for the end users. Sensors 2017, 17, 1104. [CrossRef]

22. Wen, Y.; Shang, S.; Yang, J. Optimization of irrigation scheduling for spring wheat with mulching and limited irrigation water in an arid climate. Agric. Water Manag. 2017, 192, 33-44. [CrossRef]

23. Ajaz, A.; Datta, S.; Stoodley, S. High plains aquifer-state of affairs of irrigated agriculture and role of irrigation in the sustainability paradigm. Sustainability 2020, 12, 3714. [CrossRef]

24. Brouwer, C., K. Prins, Heibloem, M. Irrigation Water Management: Irrigation Scheduling. Train. Man. 1989, 4, 66.

25. Allen, R.G.; Pereira, L.S.; Raes, D.; Smith, M. Crop Evapotranspiration-Guidelines for Computing Crop Water Requirements-FAO Project H2Olive3s; Food and Agriculture Organization (FAO): Rome, Italy, 1998; Volume 300, p. D05109.

26. Kassem, M.A. Water requirements and crop coefficient of date palm trees "Sukariah cv". Misr J. Agric. Eng. 2007, 24, 339-359.

27. Al-Amoud, A.I. Subsurface drip irrigation for date palm trees to conserve water. In Proceedings of the Acta Horticulturae, Abu Dhabi, UAE, 3 December 2010; Volume 882, pp. 103-114.

28. Ahmed, T.F.; Hashmi, H.N.; Ghumman, A.R. Performance Assessment of Subsurface Drip Irrigation System Using Pipes of Varying Flexibility. Mehran Univ. Res. J. Eng. Technol. 2011, 30, 361-370.

29. Al-Amoud, A.I.; Mohammad, F.S.; Al-Hamed, S.A.; Al-Abdulkader, A.M. Reference evapotranspiration and date palm water use in the kingdom of Saudi Arabia. Int. Res. J. Agric. Sci. Soil Sci. 2012, 2, 155-169.

30. Alikhani-Koupaei, M.; Fatahi, R.; Zamani, Z.; Salimi, S. Effects of deficit irrigation on some physiological traits, production and fruit quality of 'Mazafati' date palm and the fruit wilting and dropping disorder. Agric. Water Manag. 2018, 209, $219-227$. [CrossRef]

31. Dhehibi, B.; Salah, M.B.; Frija, A.; Aw-Hassan, A.; Ouhibi, H.E.; Raisi, Y.M. Al Economic and Technical Evaluation of Different Irrigation Systems for Date Palm Farming System in the GCC Countries: Case of Oman. Environ. Nat. Resour. Res. 2018, 8, 55. [CrossRef]

32. Yang, Y.J.; Bi, M.H.; Nie, Z.F.; Jiang, H.; Liu, X.D.; Fang, X.W.; Brodribb, T.J. Evolution of stomatal closure to optimize water-use efficiency in response to dehydration in ferns and seed plants. New Phytol. 2021, 230, 2001-2010. [CrossRef]

33. Garcia-Mier, L.; Jimenez-Garcia, S.N.; Chapa-Oliver, A.M.; Mejia-Teniente, L.; Ocampo-Velazquez, R.V.; Rico-García, E.; FeregrinoPérez, A.A.; Guevara-Gonzalez, R.; Torres-Pacheco, I. Strategies for sustainable plant food production: Facing the current agricultural challenges-agriculture for today and tomorrow. In Biosystems Engineering: Biofactories for Food Production in the Century XXI; Springer: Berlin/Heidelberg, Germany, 2014; Volume 9783319038, pp. 1-50, ISBN 9783319038803.

34. Ávila, C.; Guardiola, J.L.; Nebauer, S.G. Response of the photosynthetic apparatus to a flowering-inductive period by water stress in Citrus. Trees-Struct. Funct. 2012, 26, 833-840. [CrossRef]

35. Helaly, M.N.M.; El-Hosieny, A.M.H. In vitro selection and photosynthetic characterization of date palm regenerated seedling as affected by water stress. Am. J. Plant Physiol. 2011, 6, 126-143. [CrossRef]

36. Shafqat, W.; Jaskani, M.; Maqbool, R.; Sattar Khan, A. Evaluation of Citrus Rootstocks against Drought, Heat and their Combined Stress Based on Growth and Photosynthetic Pigments Fingerprinting of Jamun (Syzygium cumini) Genetic Resources of Punjab View project. Int. J. Agric. Biol. 2019, 22, 1001-1009.

37. Nam, S.; Kang, S.; Kim, J. Maintaining a constant soil moisture level can enhance the growth and phenolic content of sweet basil better than fluctuating irrigation. Agric. Water Manag. 2020, 238, 106203. [CrossRef] 
38. Vijendra, S.; Bajaj, S.; Bassi, A.; Vijendra, S.; Vijendra, S.; Bajaj, S.; Bassi, A.; Vij, A.; Vijendra, S.; Vij, A.; et al. ScienceDirect ScienceDirect ScienceDirect IoT and Machine Learning Approaches for Automation of Farm IoT and Machine Approaches Automation of Farm on Computational Intelligence for IoT and Machine Learning Approaches for Automation of Farm Irrigation Syst. Procedia Comput. Sci. 2019, 167, 1250-1257.

39. Xu, M.; David, J.M.; Kim, S.H. The fourth industrial revolution: Opportunities and challenges. Int. J. Financ. Res. 2018, 9, 90-95. [CrossRef]

40. Abioye, E.A.; Abidin, M.S.Z.; Mahmud, M.S.A.; Buyamin, S.; AbdRahman, M.K.I.; Otuoze, A.O.; Ramli, M.S.A.; Ijike, O.D. IoT-based monitoring and data-driven modelling of drip irrigation system for mustard leaf cultivation experiment. Inf. Process. Agric. 2020, 8, 270-283. [CrossRef]

41. Mohammed, M.; El-shafie, H.; Alqahtani, N. Design and validation of computerized flight-testing systems with controlled atmosphere for studying flight behavior of red palm weevil, rhynchophorus ferrugineus (Olivier). Sensors 2021, $21,2112$. [CrossRef] [PubMed]

42. Clarke, D.; Smith, M.; El-Askari, K. CropWat for Windows (Version 4.2); Southampton University: Southampton, UK, 1998.

43. Allen, R.G.; Pereira, L.S.; Raes, D.; Smith, M. Irrigation and Drainage, Paper No. 56-Crop Evapotranspiration; Food and Agriculture Organization of the United (FAO): Rome, Italy, 1998; Volume 56, p. e156.

44. AOAC. Official Methods of Analysis of AOAC International, 16th ed.; AOAC: Association of Official Analytical Chemists: Rockville, MD, USA, 2005.

45. Mohammed, M.E.A.; Eissa, A.H.A.; Aleid, S.M. Application of pulsed electric field for microorganisms inactivation in date palm fruits. J. Food Nutr. Res. 2016, 4, 646-652.

46. Mohammed, M.E.A.; El-Shafie, H.A.F.; Alhajhoj, M.R. Design and efficacy evaluation of a modern automated controlled atmosphere system for pest management in stored dates. J. Stored Prod. Res. 2020,89, 101719. [CrossRef]

47. Mohammed, M.; Alqahtani, N.; El-Shafie, H. Development and evaluation of an ultrasonic humidifier to control humidity in a cold storage room for postharvest quality management of dates. Foods 2021, 10, 949. [CrossRef]

48. Mohammed, M.E.A.; El-Shafie, H.A.; Sallam, A.A.A. A solar-powered heat system for management of almond moth, Cadra cautella (Lepidoptera: Pyralidae) in stored dates. Postharvest Biol. Technol. 2019, 154, 121-128. [CrossRef]

49. Kirnak, H.; Kaya, C.; Tas, I.; Higgs, D. The influence of water deficit on vegetative growth, physiology, fruit yield and quality in eggplants. Bulg. J. Plant Physiol 2001, 27, 34-46.

50. Premachandra, G.S.; Saneoka, H.; Fujita, K.; Ogata, S. Leaf Water Relations, Osmotic Adjustment, Cell Membrane Stability, Epicuticular Wax Load and Growth as Affected by Increasing Water Deficits in Sorghum. J. Exp. Bot. 1992, 43, 1569-1576. [CrossRef]

51. Hura, T.; Hura, K.; Grzesiak, M.; Rzepka, A. Effect of long-term drought stress on leaf gas exchange and fluorescence parameters in C3 and C4 plants. Acta Physiol. Plant 2007, 29, 103-113. [CrossRef]

52. Chaves, M.M.; Miguel Costa, J.; Madeira Saibo, N.J. Recent Advances in Photosynthesis Under Drought and Salinity. Adv. Bot. Res. 2011, 57, 49-104. [CrossRef]

53. Bloch, D.; Hoffmann, C.M.; Märländer, B. Impact of water supply on photosynthesis, water use and carbon isotope discrimination of sugar beet genotypes. Eur. J. Agron. 2006, 24, 218-225. [CrossRef]

54. Bruce, W.B.; Edmeades, G.O.; Barker, T.C. Molecular and physiological approaches to maize improvement for drought tolerance J. Exp. Bot. 2002, 53, 13-25. [CrossRef] [PubMed]

55. Vaz, M.; Coelho, R.; Rato, A.; Samara-Lima, R.; Silva, L.L.; Campostrini, E.; Mota, J.B. Adaptive strategies of two Mediterranean grapevines varieties (Aragonez syn. Tempranillo and Trincadeira) face drought: Physiological and structural responses. Theor. Exp. Plant Physiol. 2016, 28, 205-220. [CrossRef]

56. Ortega-Farias, S.; Espinoza-Meza, S.; López-Olivari, R.; Araya-Alman, M.; Carrasco-Benavides, M. Effects of different irrigation levels on plant water status, yield, fruit quality, and water productivity in a drip-irrigated blueberry orchard under Mediterranean conditions. Agric. Water Manag. 2021, 249, 106805. [CrossRef]

57. Chaves, M.M.; Santos, T.P.; Souza, C.R.; Ortuño, M.F.; Rodrigues, M.L.; Lopes, C.M.; Maroco, J.P.; Pereira, J.S. Deficit irrigation in grapevine improves water-use efficiency while controlling vigour and production quality. Ann. Appl. Biol. 2007, 150, $237-252$. [CrossRef]

58. Al-Khateeb, S.A.; Al-Khateeb, A.A.; El-Beltagi, H.S.; Sattar, M.N. Genotypic variation for drought tolerance in three date palm (Phoenix dactylifera L.) cultivars. Fresenius Environ. Bull. 2019, 28, 4671-4683.

59. Onoda, Y.; Hikosaka, K.; Hirose, T. Seasonal change in the balance between capacities of RuBP carboxylation and RuBP regeneration affects $\mathrm{CO}_{2}$ response of photosynthesis in Polygonum cuspidatum. J. Exp. Bot. 2005, 56, 755-763. [CrossRef] [PubMed]

60. Ribeiro, R.V.; Machado, E.C. Some aspects of citrus ecophysiology in subtropical climates: Revisiting photosynthesis under natural conditions. Brazilian J. Plant Physiol. 2007, 19, 393-411. [CrossRef]

61. Manzoor Alam, S. Nutrient Uptake by Plants Under Stress Conditions. Handb. Plant Crop Stress 1999, 2, 285-313. [CrossRef]

62. Bainbridge, D.A. Deep Pipe Irrigation. The Overstory\# 175. Permanent Agriculture Resources, Holualoa, Hawaii. 2006. Available online: http:/ / www.overstory (accessed on 23 August 2021).

63. Al-Amoud, A.I. Date palm response to subsurface drip irrigation. In In ASABE Annual Meeting; American Society of Agricultural and Biological Engineers. In Proceedings of the CSBE/SCGAB Annual Conference, Edmonton, AB, Canada, 16-19 July 2006. 
64. Sade, N.; Del Mar Rubio-Wilhelmi, M.; Umnajkitikorn, K.; Blumwald, E. Stress-induced senescence and plant tolerance to abiotic stress. J. Exp. Bot. 2018, 69, 845-853. [CrossRef] [PubMed]

65. Moshelion, M.; Halperin, O.; Wallach, R.; Oren, R.; Way, D.A. Role of aquaporins in determining transpiration and photosynthesis in water-stressed plants: Crop water-use efficiency, growth and yield. Plant Cell Environ. 2015, 38, 1785-1793. [CrossRef] [PubMed]

66. Pessarakli, M. Plant Responses under Environmental Stress Conditions. Adv. Plants Agric. Res. 2015, 2, 73. [CrossRef]

67. Gong, Z.; Xiong, L.; Shi, H.; Yang, S.; Herrera-Estrella, L.R.; Xu, G.; Chao, D.Y.; Li, J.; Wang, P.Y.; Qin, F.; et al. Plant abiotic stress response and nutrient use efficiency. Sci. China Life Sci. 2020, 63, 635-674. [CrossRef] [PubMed]

68. Mattar, M.A.; Soliman, S.S.; Al-Obeed, R.S. Effects of various quantities of three irrigation water types on yield and fruit quality of 'succary' date palm. Agronomy 2021, 11, 796. [CrossRef]

69. Al-Yahyai, R.; Al-Kharusi, L. Sub-optimal irrigation affects chemical quality attributes of dates during fruit development. Afr. J. Agric. Res. 2012, 7, 1498-1503. [CrossRef]

70. Steyn, W.J.; Wand, S.J.E.; Jacobs, G.; Rosecrance, R.C.; Roberts, S.C. Evidence for a photoprotective function of low-temperatureinduced anthocyanin accumulation in apple and pear peel. Physiol. Plant 2009, 136, 461-472. [CrossRef]

71. Ikeda, T.; Suzuxj, N.; Nakayama, M.; Kawakami, Y. The effects of high temperature and water stress on fruit growth and anthocyanin content of pot-grown strawberry (Fragaria $\times$ ananassa Duch. cv. 'Sachinoka') plants. Environ. Control Biol. 2011, 49, 209-215. [CrossRef] 